\title{
PROBLEMS OF SYNONYMY IN THE MEDICAL TERMINOLOGY OF THE ENGLISH, RUSSIAN AND TATAR LANGUAGES \\ Venera Khisamova ${ }^{1}$, Liliia Abdullina ${ }^{2 *}$, Leila Nurgalieva ${ }^{3}$, Zukhra Motygullina ${ }^{4}$ \\ ${ }^{1}$ Professor, Doctor of Philological Sciences, Institute of International Studies, Kazan Federal University, Russia; \\ ${ }^{2 *}$ Lecturer, Institute of International Studies, Kazan Federal University, Russia; ${ }^{3,4}$ Associate Professor, Candidate of \\ Philological Sciences, Institute of International Studies, Kazan Federal University Russia. \\ Email: ${ }^{1}$ hisamovaven@yandex.ru, ${ }^{2 *}$ lilia-2591@ mail.ru, ${ }^{3}$ lanurgalieva@ kpfu.ru, ${ }^{4}$ zamotygullina@kpfu.ru
}

\section{Article History: Received on $18^{\text {th }}$ January 2020, Revised on $24^{\text {th }}$ March 2020, Published on $27^{\text {th }}$ May 2020}

\begin{abstract}
Purpose of the study: This study is undertaken to identify the similarities and differences of synonymous relations in the medical terminology of English, Russian and Tatar languages.

Methodology: To identify the common and special in the compared languages, a comparative method is used. The basis of comparison in the medical terminology of genetically unrelated languages was established. In this study, the method of feature comparison was used, i.e. the phenomenon of synonymy was studied in a comparative aspect.
\end{abstract}

Main Findings: The results of this study contribute to the selection of the correct, appropriate synonym for the term when translating into medical texts. Comparative analysis of three languages in the matter of synonyms in medical terminology has shown that English and Russian languages have more similarities than English and Tatar ones and Russian and Tatar ones.

Application of the study: This study is of great importance in compiling dictionaries. At the same time, it will help students of the medicine faculty with the translation of medical texts, taking into account the peculiarities of the synonymy of terms in each language.

Novelty: The synonymy in the medical terminology of genetically unrelated languages, in particular, English and Tatar languages, Russian and Tatar languages has not been studied to date in a comparative aspect.

Keywords: Synonymy, Medical Terminology, English Language, Russian Language, Tatar Language, Terms.

\section{INTRODUCTION}

The study of medical terminology is one of the advanced directions in modern science, since the vocabulary of languages, including national ones, is filled up by terminology. New terms appear as a result of new discoveries, scientific achievements in the field of medicine. The problem of the synonymy of terms, i.e. the use of several special lexical units for naming a single concept, through present continues to be one of the most important problems of terminology. There are discussions regarding the phenomenon of synonymy in terminology: some scholars believe that there should not be synonyms in terminology, others allow only absolute synonyms, others believe that the phenomenon of synonymy cannot ignore terminology since the term is not a special word, but a word in a special function and it has the same lexical-semantic phenomena as the common word. There is debate about the stylistic neutrality of the term, which means that there can be no stylistic synonyms in terminology, but despite these requirements, stylistic synonyms still occur in terminology (especially euphemisms that are especially significant in medical ethics, medical slang). Moreover, the synonymy in the medical terminology of genetically unrelated languages, in particular, English and Tatar languages, Russian and Tatar languages has not been studied to date in a comparative aspect.

The study of synonymy in the medical terminology of the English, Russian and Tatar languages will determine the general qualities and specific features of the synonymous relations in these languages, which helps to order the terms in the English, Russian and Tatar languages, compile dictionaries, indicating the entire synonymous series and nature of these synonyms (borrowed term, common variant, obsolete form, eponym, euphemism, slang, etc.) and help students of medical faculties when translating the medical texts taking into account peculiarities of the given languages.

This paper is devoted to the study of synonymy in the medical terminology of the English, Russian, and Tatar languages. English is the international language of science, Russian is the national language of the Russian people and, at the same time, it is spread in the world. The Russian language takes the sixth place among all languages in the number of speakers and eighth in the number of native speakers, and Tatar language, as the national language in the Russian Federation, takes the second place in terms of prevalence and the number of speakers (Khisamova, 2011: 68-69). The paper also discusses the ways of appearing of synonyms. Synonymy in medical terminology plays a key role. The use of synonyms is appropriate when the doctor communicates with the patient, so the doctor may use a more understandable or milder term for the patient.

Greco-Latin terms form the basis of medical terminology, therefore they are a source of synonymy in all three languages, as they are used in medical language along with national terms, and there can be the terms of Greek origin and Latinized ones as well. It is important to note the fact that the Russian language is an intermediary in the penetration of terms of foreign origin into the Tatar language. 


\section{THEORETICAL BACKGROUND}

According to Smirnova (2011: 190), synonymy of terms is a type of semantic relations based on the ability of different terminological units to designate one special concept, expressing various additional signs of the concept, emotional or stylistic nuance, usability and co-occurrence with other terminological units.

\section{Synonymy is a positive phenomenon in terminology from the point of view of scientists}

Some scientists (S.V. Grinev-Grinevich, V.M. Leychik, N.V. Novodranova) regard terminological synonymy as a positive phenomenon. GrinevGrinevich (2008: 102-105) writes that the problem of synonymy is one of the most important problems of terminology. In his opinion, sources of semantic equivalence in terminology are: metadialects of various scientific schools and idiolects of individual researchers, variation of the term's forms (Eng. angioma - vascular tumour, Rus. gastrorragia-zheludochnoye krovotechenie/gastrorrhagia, Tat. abstsess - erenle şeş/abscess etc.), use in nominations of various aspects of an object (Eng. tumor - growth, Rus. opukhol'-novoobrazovaniyeltumor, Tat. söyäk celege - sari celek/bone marrow etc.), borrowing a term followed by the appearance of a semantic doublet in the native language (Eng. myopia - shortsightedness, Rus. miopia - blizorukost'/shortsightedness, Tat. myopia - kürä qarau/shortsightedness etc.), or simultaneous borrowing of two equivalent terms (Eng. proctoscopy - rectoscopy, Rus. angiopatia-vasopatia/angiopathy - vasopathy, Tat. proktoskopia - rektoskopia/proctoscopy - rectoscopy etc.), the existence of official and colloquial terms (Eng. conjunctivitis - pink eye, Rus. epidemicheskiy parotit - svinka/epidemic parotitis, Tat. flyus - teş baqasi/parulis etc.), modern and obsolete terms (Eng. edema - dropsy, Rus. epilepsia paduchaya nemoch'lepilepsy, tat. sirxau - aviru/ill etc.), full and short variants (Eng. antibiotic remedies - antibiotics, Rus. antibioticheckie lekarstva antibiotiki/antibiotic remedies - antibiotics, Tat. antibiotic darular - antibiotiklar/ antibiotic remedies - antibiotics etc.).

The problem of the synonymy of concepts and ideas naming for special and common vocabulary is not unique. In common vocabulary, it has a positive meaning: synonyms are used to make speech more graphic and are one of the most expressive means of stylistic realization of the text. In this regard, the traditional and for lexicology problem of synonymy was developed not so much in the aspect of determining the degree of equivalence of potential substitutions, as in order to highlight differences and study stylistic functions of roughly equivalent means of expressing concepts.

In common vocabulary, the full equivalence of meaning is practically absent. This means that we have different, although close within the meaning words. There are two main types of synonyms: ideographic (multidisciplinary) synonyms, distinguished by shades of meaning, and stylistic synonyms that have a positive or negative connotation and belong to different style levels.

In the sphere of special vocabulary, the problem of equivalence of the meaning of words acquires a completely different character. On the one hand, scientific speech is intended to convey information, rather than achieve stylistic effects. Stylistic neutrality is considered by most terminologists to be an inherent property, a sign of the term; therefore, there are not stylistic synonyms in the sphere of terminolexics. On the other hand, even an insignificant difference of similar words means that we are talking about two close, but, nevertheless, different concepts and, therefore, different terms. If the terms denote the same concept, then they, as a rule, are absolutely equivalent in meaning. That's why taking into account the different nature of synonymy in the common vocabulary and language of science, it was proposed to use the term doublet for this phenomenon in the terminology, as shown in the following examples, e.g., Eng. oculist - eye doctor, Rus. oculist - glaznoy vrach/eye doctor, Tat. oculist - küz vraçi/eye doctor. In 1970 variants of terms have appeared in the professional literature. In this case, the concepts of synonym, doublet, variant were considered as equivalent, sometimes variants were considered as a kind of synonyms, and duplicates - as lexical variants. In this regard, a generalizing term terminological equivalents were introduced, however, it is used to denote interlanguage terminological equivalents.

S.V. Grinev-Grinevich, considering all these circumstances, the relationship of total and relative synonymy of terms (for which the term synonymy is used), as well as the equivalence of different terms, suggests the term 'equivalence'.

Equivalent terms are terms with the same or similar meaning, used to name a single concept. In accordance with the basic types of equivalence and current trends in the use of terms, equivalent terms can be divided into terms-synonyms (synonymous terms) - terms of the same language with the same or similar meaning (equivalent terms of the same language), as shown in the following examples, e.g., Eng. nearsightedness - shortsightedness, Rus. opukhol' novoobrazovanie/tumor, Tat. kürä qarau - eraqtan kürməüçelek/shortsightedness, and equivalents - multilingual terms with the same or similar meaning (multilingual equivalent terms), e.g., Eng. hypermetropia - farsightedness, Rus. gipermetropia-dal'nozorkost'ffarsightedness, Tat. gipermetropia - yaqinnan kürmä̈ilfarsightedness).

Leychik (1973:104) also accepts the phenomenon of synonymy in terminology, but, nevertheless, he notes that there can be no stylistic synonyms in terminology since a lexical unit relating to conversational style, colloquial language, jargon, and professional vocabulary cannot be part of the terminological system.

According to the document of the standardization of medical terminology under the headline "Informatization of health. Controlled medical terminology. Structure and high-level indicators" several terms can have the same meaning if they are exact representations of the same concept. This implies the absence of redundancy, ambiguity, uncertainty, and 
internal consistency (National standard of the Russian Federation, 2012: 3).

\section{Synonymy as an undesirable phenomenon in terminology from the point of view of scientists}

Some researchers (D.S. Lotte, V.K. Favorin, V.P. Danilenko, E.N.Tolikina, O.S. Akhmanova) consider that synonymy in terminology is undesirable. e.g., Lotte $(1941: 9,10)$ notes that even total synonyms can be harmful. There is a danger that content either narrower than the other, or broader, or, finally, completely different is gradually embedded in one of these terms. Thus, total synonyms are turned into relative ones with all the vices of multivalent terms. He concedes only two cases of synonymy in terminology: 1 . When there is a need to put different characteristics of the same concept in a basis for building different systems of terms or to give different constructions to terms composed of the same lexical elements; 2 . The presence of synonyms of terms, one of which is a short form of the other, i.e. contains terms that are part of another term but in a smaller number or abbreviated form. Tolikina $(1970: 61,62)$ believes that there can only be doublets in terminology. In her opinion, the doublet is an undesirable phenomenon, since it does not give either stylistic nuance or individuality, but simply speaks of the disorder of terms. Akhmanova (1966:13), on the contrary, writes that it is necessary to free the terminology from doublets as soon as possible, since they are not synonyms, but simply name the same object in different ways.

\section{Synonymy is a widespread phenomenon in the medical terminology}

Terminological synonymy should not be considered separately from the synonymy of common lexis, because the term is not a special word, but a word in a special function, it should have the same linguistic phenomena like any other word of the commonly used language. This state of affairs does not give grounds to speak about terminological synonymy as a negative and redundant phenomenon or to deny it all together (Taranova, et al., 2016: 58; Motchenko, 2001: 155).

In our article, we will talk about equivalent terms that are interchangeable, as shown in the following examples, e.g., Eng. "Mitral valve regurgitation (mitral incompetence, mitral insufficiency) is leakage back through the mitral valve each time the left ventricle contracts. E.g. corticosteroids (cortisone-like drugs) may produce acne cause skin to become thin, and anticoagulants (blood thinners) may cause bruising when blood leaks under the skin" (Berzegova, 2008: 34, 216); Rus. "Allergicheskiy rinit klinicheski kharakterizuetsya nalichiem odnogo ili bolee iz sleduyuschikh simptomov: zud $v$ nosovoypolosti, chikhaniye, zalozhennost' nosa, rinoreya (perednyaya ili zadnyaya) i, inogda, snizheniye obonyaniya (giposmiya)"./Allergic rhinitis is clinically characterized by the presence of one or more of the following symptoms: nasal itching, sneezing, nasal congestion, rhinorrhea (anterior or posterior), and, sometimes, reduction in smell (hyposmia) (Chotchayeva et al., 2018). "Prichinoi gipertonicheskogo kriza mozhet bit' kak gipertonicheskaya bolezn' (essentsial'naya AG) (70\%), tak i simptomachiskie AG (v t.ch. feokhromotsitoma, tireotoksikoz, vazorenal'naya $A G)$, a takzhe nekotorie drugie sostoyania (ostriy glomerulonephrit, cherepno-mozgovaya travma, preeclampsia $i$ eclampsia beremennikh $i \mathrm{dr}$.). "'/Hypertensive crisis can be caused by both hypertensive disease (essential hypertension) (70\%) and symptomatic hypertension (including pheochromocytoma, thyrotoxicosis, renovascular hypertension), as well as some other conditions (acute glomerulonephritis, traumatic brain injury, pre-eclampsia and eclampsia of pregnant women and others.) (Filippova,2018). "Ayaqlardaği qara qan tamirlariniñ (venalarniñ) varikoz kiñäyüe şundiy xronik çirlärneñ ber tore. "Naricose veins of the lower extremities are one of the varieties of such chronic diseases (Salikhov, 2013). "Monda yöräkneñ citlekle eshlämäve, kardiomiopatia, yăgni, yöräk yalqinsinui diagnosi kueldi."/There was diagnosed heart failure, cardiomyopathy, or heart muscle damage (Garifullina, 2018).

The widespread use of synonymy in medical terminology is caused by the following factors: synonymy arises from the search for a more rational designation; the same field develops simultaneously in different countries, and under the condition, scientists communicate and exchanging experience, an exchange of terms occurs; authors in their publications introduce their own terms for newly emerging concepts; the foreign language term is also introduced into the national language as a synonym for an already existing term due to brevity since brevity is another requirement for a term (Motchenko, 2001:159; Schekoldina, 2006:143).

Danilenko(1977: 73) writes that synonymy is especially characteristic of the early stages of the formation of the term system when several terms were proposed for the concept and there was no natural or artificial selection of the best term.

\section{Sources of terminological synonymy in English medical terminology}

There are the following sources of terminological synonymy in English medical terminology:

1. Greek-Latin synonymy, when both Greek and Latin terms are used to express the same concept, as shown in the following examples, e.g., proctoscopy - rectoscopy, pneumonectomy - pulmonectomy, microangiopathycapillaropathy, etc.

2. Synonymy of borrowed and native English terms, as shown in the following examples, e.g., patella - kneecap, uterus - womb, vertigo - dizziness, etc.

3. Synonymy of original English terms, as shown in the following examples, as shown in the following examples, e.g., pins and needles - tingling, graze - scratch, nearsightedness - shortsightedness, etc.

4. Synonymy of eponyms and their meanings, as shown in the following examples, e.g., Patau's syndrome-trisomy 13, 
Bazin's disease - erythema induratum, Charcot's joints - neurogenic joint degeneration, etc.

5. Synonymy of the term and its equivalent from a common language, as shown in the following examples, e.g., amniotic fluid - waters, inhaler - puffer, bulla - blister, etc.

6. Synonymy of the modern term and its obsolete form, as shown in the following examples, e.g., dysentery - bloody flux, syphilis - French pox or French disease, edema - dropsy, etc.

7. Synonymy of the term and its euphemistic meaning, as shown in the following examples, e.g., cancer - big C, long illness, mitotic disease; crippled - differently-abled, surgery - intervention, etc.

8. At the stage of polysemous models, some of them may be synonymous along with anyone's semantic line. With the development of medicine, there is a refinement of concepts, the emphasizing of new signs of phenomena. This finds expression in linguistic forms - synonyms, which are an active linguistic means of fixing a new view on an object of thought, as shown in the following examples, e.g., bioassay - bioanalysis - bioprobe - biotest / biological analysis; nicotinic acid - niacin - vitamin PP; mode - type - kind - manner - way - course of action - shape; alternative medicine - unconventional medicine - alternative / unconventional therapeutic practices - alternative / unconventional techniques (Motchenko, 2001: 176).

9. Synonymy of the term and slang, as shown in the following examples, e.g., sudden seizure attack - fits, acute appendicitis - pothole sign, endotracheal tube - snorkel, etc.

10. Synonymy that occurs during the combined translation method (in most cases, Greek-Latin terms): transliteration and calquing, as shown in the following examples, e.g., hemostasis - blood stasis, pleuropneumonia - lobar pneumonia, hemotransfusion - blood transfusion, etc.

11. Synonymy, resulting from the use in the nomination of various aspects of an object, as shown in the following examples, e.g., tumor - growth, hay fever - summer catarrh, adult tooth - double tooth, etc.

12. Equivalent synonyms also include variants. They can be divided in virtue of the sign of completeness (full and short) and the language level at which the form of the terms is varied: the full version is a variant that includes the maximum set of term elements of the term; short version - option obtained by shortening the full term, as shown in the following examples, e.g., antiseptic devices - antiseptics, antibiotic remedies - antibiotics, tuberculous protein tuberculoprotein, etc.

13. When dividing on the basis of a sign of the language level, the following types of variants are distinguished: graphical variants - variants that differ only in writing, as shown in the following examples: e.g., tumor - tumour, curet - curette, haemophilia - hemophilia, etc., phonetic -graphic variants are variants that differ in pronunciation and varying spelling of identical lexemes, as shown in the following examples, e.g., nocturia-nycturia, word-formation, differing only in derivational affixes, as shown in the following examples, e.g., cough - coughing, vomit - vomiting, faint - fainting, from Greek and Latin cardiomegaly - megalocardia, pyelonephritis - nephropyelitis etc., syntactical variants - variants of term-phrases differing in the syntax model of formation (word order and relationship between them), as shown in the following examples, e.g., lung cancer - cancer of the lung, intestinal activity - activity of intestine, urinary tract infection - infection of urinary tract etc.

14. Morphological-syntactic variants are variants, one of which is a term-phrase or a complex term, and the other is its short variant obtained by means of syntactic and morphological transformations. Most often, short variations are words or word-like formations. There are the following types of morphological and syntactic variants in English: elliptical variants - morphological and syntactic variants formed by an ellipsis (omitting one of the components) of a multi-component term without changing its meaning, as shown in the following examples, e.g., left atrium of the heart - left atrium, ABO blood group system - ABO system, arterial blood vessel - arteria, etc., abbreviated variants morphological and syntactic variants, formed by adding together parts of words, initial letters and/or sounds of a multi-component term, as shown in the following examples, e.g., GIS - gastro-intestinal system, CV - cardiovascular, COPD - chronic obstructive pulmonary disease, etc.

15. Synonymy of terms that occurs inside medicine. When a phenomenon within a field of medicine receives several terminological expressions, intra industry terminological synonymy arises, as shown in the following examples, e.g., surgery - operation, roentgenology - radiology, assimilation - anabolism, etc. (Motchenko, 2001: 157-158).

\section{Sources of terminological synonymy in Russian medical terminology}

In Russian medical terminology, the following sources of synonymy are distinguished:

1. Greco-Latin synonymy, as shown in the following examples, e.g., angiopatia - vasopatia/angiopathy - vasopathy, koloproktit - $\quad$ kolorektit/coloproctitis $\quad-\quad$ colorectitis, radiopnevmographia/radiopulmonography - radiopneumography, etc.

2. Synonymy of borrowed and native Russian terms, as shown in the following examples, e.g., dispnoe - odishka/ shortness of breath, lipoma - zhirovik/lipoma, palatoskhizis - raschelina neba/cleft palate, insomnia - 
bessonnitsa/insomnia, etc.

3. Synonymy of native Russian terms, as shown in the following examples, e.g., bolezn'-zabolevanie/disease, sinyakkrorvopodtek/bruise, drozh'-oznob/shivering, etc.

4. Synonymy of eponyms and their meanings, as shown in the following examples, e.g., bolezn' Allopo - pustulezniy akrodermatit/Allopo's disease - pustular acrodermatitis, sindrom Pika - psevdotsirroz pecheni/Pick's syndrome pseudocyrrhosis of the liver, symptom Zilberlast-Zand - symptom trepetaniya vek/Zilberlast-Zand's symptom — a symptom of eyelid flutter, etc.

5. The synonymy of the term and its equivalent from the common vocabulary, as shown in the following examples, e.g., parotit - svinka/parotitis - mumps, tuberkulez - chakhotka/tuberculosis, potnitsa - prosyanka/sweating fever, trikhoma - koltun/trichome, etc.

6. The synonymy of the term and its obsolete equivalent, as shown in the following examples, e.g., parotit zaushnitsa/parotitis, angina - gorlovaya zhaba/sore throat, epilepsia-paduchaya bolezn'lepilepsy, etc.

7. Synonymy of the term and its euphemistic meaning, as shown in the following examples, e.g., smert'-letal'niy iskhod/death, psikhicheskie bolezni - dushevnie zabolevaniya/mental illness, ozhireniye - izbitochniy ves/obesity, etc.

8. Synonymy of the term and slang, as shown in the following examples, e.g., epidural'naya anesteziya epiduralka/epidural anesthesia, klinicheskaya smert' - klinika/clinical death, mertsatel'naya aritmia mertsalka/atrial fibrillation etc.

9. Synonymy that occurs during the combined translation method (in most cases, Greek-Latin terms): transliteration and calquing, as shown in the following examples, e.g., gemostaz - staz krovi/hemostasis - blood stasis, panbronkhit glubokiy bronkhit/panbronchitis, onkomarker - opukholeviy immunomarker/tumor marker, etc.

10. Synonymy resulting from the use in the nomination of various aspects of an object, as shown in the following examples, e.g., opukhol' - novoobrazovanie/tumor, sinyak - krovopodtek/bruise, oprelost' - pelenochnaya sip'/diaper, etc.

11. Synonyms - full and short variants, as shown in the following examples, e.g., antisepticheskoe sredstvo antiseptic/antiseptic, analgeziruyush'ee sredstvo - analgetik/analgesic, diureticheskie sredstva - diuretiki/diuretic, patologicheskaya phisiologia - patophisiologia/pathological physiology - pathophysiology, etc.

12. Synonyms - phonetic-graphics variants, as shown in the following examples, e.g., venopunktsia venepunktsia/venipuncture, perikardiotomia - perikardotomia/pericardiotomy, arteriektomia arterektomia/arteriectomy, gastroskhizis-gastrosshizis/gastrosshizis, periangit-periangiit/periangitis etc., synonyms -word-forming variants, e.g., prirozhdenniy-vrozhdenniya/congenital, vekoderzhatel'-vekouderzhivatel'/eye speculum, pripukhlost' - nabukhanie/swelling, from Greek and Latin kardiomegalia - megalokardia/cardiomegaly megalocardia, gastroezofagostomia - ezofagogastrostomia/gastroesophagostomy - esophagogastrostomy, kardioangiographia - angiokardiographia/angiocardiography, pielonephrit - nephropielit/pyelonephritis nephropyelitis, etc.

13. From the morphological-syntactic variants in Russian, abbreviated variants of terms are distinguished, as shown in the following examples, e.g., MRT - magnitno-rezonansnaya tomographia/MRI - magnetic resonance imaging, UZI - ul'trazvukovoe issledovanie/ultrasound, ZhKT - zheludochno-kishechniy tract/gastrointestinal tract etc.

14. Intra-industry synonymy, as shown in the following examples, e.g., reaktsia - proba/reaction-sample, shina longeta/splint, radiologia - rentgenologia/radiology-roentgenology, etc.

\section{Sources of terminological synonymy in Tatar medical terminology}

The following sources of synonymy in medical terminology were found out in the Tatar language:

1. Greek-Latin synonymy, as shown in the following examples, e.g., angiopatia - vasopatia/angiopathy - vasopathy, proktoskopia - rektoskopia/proctoscopy - rectoscopy, pnevmonektomia - pulmonektomia/pneumonectomy pulmonectomy, etc.

2. Synonymy of borrowed and native Tatar terms, as shown in the following examples, e.g., abort - bala töşerü/abortion, laringit - tamaq yalqinsinu/laryngitis, oftalmolog - küz vraçi/oculist, etc.

3. Synonymy of the original Tatar terms, as shown in the following examples, e.g., cilsenü - yalqinsinu/inflammation, babasir - sualçan/worm, sañğirau - çuqraq/deaf, etc.

4. Synonymy of eponyms and their meanings, as shown in the following examples, e.g., Bazedov avirui - ăguli diffuz zob/Grave's disease - diffuse toxic goiter, Qvinke şeşenue - allergic aviru/Quincke's edema - angioedema, Ognev operatsiyäse - perikard operatsiyäse/Ognev's operation, etc.

5. Synonymy of a term and its equivalent from a commonly used language, as shown in the following examples, e.g., 
çäç - tök/hair, aviru - xasta/disease, flyus - teş baqasi/parulis, etc.

6. The synonymy of the modern term and its obsolete form, as shown in the following examples, e.g., aviru - sirkhau/ill, epilepsia - ziyandaş/epilepsy, meditsina - tiyb ğiyleme/medicine, etc.

7. Synonymy of the term and its euphemistic meaning, as shown in the following examples, e.g., tuberculez tbs/tuberculosis, rak - yaman şeş/cancer, chuqraq - qolaqqa saq/deaf, etc.

8. Synonymy arising from the combined translation method, as shown in the following examples, e.g., plevropnevmonia - krupoz pnevmonia/pleuropneumonia - croupous pneumonia, psevdomelanoz - yalğan melanoz/pseudomelnaosis, vaktsinoterapia - vaktsina belän dävalau/vaccine therapy, etc.

9. Synonymy resulting from the use in the nomination of various aspects of an object, as shown in the following examples, e.g., sari celek - söyäk celege/bone marrow, analiq bizläre - kükäileklär/ovaries, sülle eren - qanli eren/serosanguinous fluid, etc.

10. Synonyms - full and short variants, as shown in the following examples, e.g., antibiotic darular antibiotiklar/antibiotic remedies - antibiotics, antiseptic çaralar - antiseptiklar/antiseptic devices - antiseptics, diuretic çaralar - diureticlar/diuretic agents - diuretics, etc.

11. Synonyms - abbreviation variants and their complete form, as shown in the following examples, e.g., DNK dezoxyribonuclein kislotasi/desoxyribonucleic acid, SPID - yäşä̈ däverendä barliqqa kilgän immunitet citkesezlege/acquired immune deficiency syndrome, UZI - ul'trataviş belän tikşerü/ultrasonography, ADG antidiuretic gormon/antidiuretic hormone, AB -arterial' basim/BP - blood pressure, VICh - keşe, immunodefitsiti virusi/HIV - human immunodeficiency virus, ORVI - ütä köçle tin yullari infektsiyäselacute respiratory viral infection, etc.

As is evident from the foregoing, Russian abbreviations are very often used in the Tatar language, although the term is interpreted in the Tatar language. This is explained by the fact that these abbreviations have national terms in their composition, therefore complete form is translated into Tatar, and the abbreviation itself remains in Russian, so it helps to avoid too long and incomprehensible abbreviations, as shown in the following examples, e.g., SPID/AIDS, ORVI/ARVI, etc. Some Tatar abbreviations are equivalent to Russians, as shown in the following examples, e.g., DNK - dezoxyribonuclein kislotasi/DNA - desoxyribonucleic acid, ADG - antidiuretic gormon/ ADH - antidiuretic hormone etc. Here, abbreviations are composed of international terms that coincide in their external form (taking into account the appropriate corresponding sound, graphic units, grammatical features) when translated into Tatar.

12. Intra-industry synonymy, as shown in the following examples, e.g., reaktsia - proba/reaction-sample, assimilyatsiaanabolism/assimilation-anabolism, radiologia - rentgenologia/radiology-roentgenology, etc.

13. Synonymy of the borrowed term and its description, consisting of its own words and representing rather the interpretation, rather than the name of the term (a frequent occurrence in the Tatar language), as shown in the following examples, e.g., virus - yogişli avirular tudiruçi bik vaq microorganism/virus, koksit - yanbaşs söyäge buini yalqinsinu/coxitis, dermatology - tire avirulari belgeçe/dermatologist, etc.

14. Borrowed words that have the same root, but refer to different parts of speech (noun + adjective, which is a clipped form of the borrowed word or consisting of a borrowed part and a word or a word-formational affix of the Tatar language), as shown in the following examples, e.g., psixiatria (xastaxanäse) - psixiatrik (xastaxanä)/psychiatric (hospital), microscop (yärdäme belän eshlängän analiz) - microscopic (analiz)/ microscopic (analysis), kontuziya alğan - kontuziyälängän/contused, etc.

\section{METHODOLOGY}

The terms for research were taken from Dictionary of English medical terms, Great encyclopedic dictionary of medical terms, Medical Russian-Tatar Explanatory Dictionary, Dictionary of synonyms of the Russian language, Dictionary of synonyms of the Tatar language, Illustrated Medical Dictionary of Dorland. Our study is based on comparable interpretations: synonyms in medical terminology are studied in each individual language, and the results are compared, which makes it possible to identify common and distinctive sources of synonymy in the medical terminology of the three languages.

\section{RESULTS}

Thus, we have revealed the following similarities and differences in the synonymy of the medical terminology of the English, Russian, and Tatar languages. The similarities are:

1. Greek, Latin, or Greek and Greek-Latin terms enter into a synonymous relationship in English, Russian, and Tatar languages. This is because they are international. Medicine as a science was founded in ancient Greece then continued its development in the Roman Empire, where many medical Greek terms were Latinized. This contributed to the use of Greek and Latin terms in medicine. In addition, these languages are rich in derivational terminology elements, are dead languages, and do not change (Doncu \& Andronache 2014: 348, 349). 
2. Borrowed and original terms are synonymous in English, Russian, and Tatar languages. Such synonymy occurs when the borrowed term is attempted to be explained by means of the national language.

3. The following similarity of the three languages is that the original terms enter into synonymous relations.

4. In all three languages, eponyms and their interpretation are also synonymous.

5. The synonymy of the term and the word from the commonly used language is peculiar to English, and Russian, and Tatar. Synonyms from common vocabulary are used in the "doctor-patient" discourse because such a term is also understood by a non-specialist (Smirnova, 2011: 193).

6. In English, Russian, and Tatar, synonyms are the term and its obsolete equivalent. Such terms can be used in the texts of archaic style.

7. In all three languages, euphemisms enter into a synonymous relationship. Euphemism arises for a number of extralinguistic and pragmatic reasons (politeness, delicacy, decency, the desire to veil the negative essence of individual phenomena of reality) (Motchenko, 2001: 169).

8. There is a synonymy that arises in the combined translation of a borrowed term in all the languages we study.

9. Also, synonymy in the medical terminology of the English, Russian and Tatar languages results from the use of various aspects of the same object in the nomination.

10. Intra-industry synonymy is common to all three languages. In this case, the term used in various scientific fields has this synonym only within the framework of medicine.

11. There are synonyms - full and short variants in English, Russian and Tatar languages.

12. There are equivalent synonyms - morphological-syntactic variants, namely, abbreviated variants and their interpretation in all the languages we are considering.

The following differences have been found:

1. The term and its slang equivalent are synonyms in English and Russian medical terminology. Slang is often used in the speech of medical figures.

2. Synonyms - phonetic and graphic variants that differ in pronunciation and variant spelling, word-forming ones, differing in derivational affixes, are often found in English and Russian, but Greco-Latin word-forming variants can be in the Tatar language as well, as shown in the following examples, e.g. kardiomegalia megalokardia/cardiomegaly - megalocardy, etc.

3. At the stage of polysemic models, some of them may be synonyms along one semantic line in English. When clarifying concepts, new features are highlighted with the development of medical science. In such cases, synonyms are an active language tool for fixing a new view on a concept.

4. Synonyms - graphical variants that differ in their spelling, syntactic variants, differing in the syntactic model of formation (the order of words and the relationship between them) are peculiar to the English language.

5. The following type of synonymous relations in English medical terminology is morphological and syntactic variants formed by an ellipse (omission of one of the components) of a multi-component term without changing its meaning.

6. In the Tatar language, the synonymy of the term and its descriptions is presented. Such terms have their advantages: a high degree of coverage of the conceptual field of the expressed concept. The compound term allows reflecting not only categorical features but also peculiar, particular, specific features (Shamsutdinova, 2000: 103).

7. Borrowed words that have the same root, but belong to different parts of speech enter into a synonymous relationship in the Tatar language.

\section{CONCLUSION}

Despite the fact that synonymy in terminology is an undesirable phenomenon, it exists and even has a positive side, especially when a doctor communicates with a patient. When translating from one language to another, the use of synonyms helps to avoid repetition. The results of this study contribute to the selection of the correct, appropriate synonym for the term when translating medical texts. Comparative analysis of three languages in the matter of synonyms in medical terminology has shown that English and Russian languages have more similarities than English and Tatar ones and Russian and Tatar ones. The results contribute to the understanding of specific linguistic, typological differences and universal features as well.

\section{LIMITATION AND STUDY FORWARD}

This study presents only sources of synonymy in three languages. The types of synonyms - absolute and partial ones and their subtypes- are not considered. They will be investigated in the future. 


\section{ACKNOWLEDGMENT}

We are thankful to the Professors of the Institute who extended their support throughout the writing of this Study.

\section{AUTHORS' CONTRIBUTION}

Research design development has been done by V.N. Khisamova. Obtaining data for analysis and analysis of the data has been done by V.N. Khisamova, Z.A. Motygullina. Writing the text of the manuscript has been done by L.I. Abdullina. A review of publications on the topic of the article has been done by L.A. Nurgalieva.

\section{REFERENCES}

1. Akhmanova, O. (1966). Slovar' lingvisticheskikh terminov [Dictionary of linguistic terms]. Moscow: Sovetskayaentsiklopediya.

2. Babenko, L. (eds.), 2011. Slovar' sinonimo v russkogo yazyka [Dictionary of Synonyms of the Russian Language]. Moscow: Astrel.

3. Berzegova, L. (2008). Different types of disease. Symptoms and treatment. Moscow: GEOTAR-Media.

4. Chotchayeva, A. A., Kolotilina, A. I., Korsunsky, I. A., Smirnova, G. I., Asmanov, A. I., Moonblit D. B.(2018). Allergicheskiy rinit: podkhody $k$ diagnostike $i$ lecheniyu. [Allergic rhinitis: approaches to diagnosis and treatment]. Russkiy meditstsinskiy zhurnal [Russian Medical Journal].https://www.rmj.ru/articles/pediatriya/Allergicheskiy_rinit_podhody_k_diagnostike_i_lecheniyu/.

5. Case, A. (2017). Colloquial expressions for medical terms. Using English.com.https://www.usingenglish.com/articles/colloquial-expressions-for-medical-terms.html/.

6. Danilenko, V. (1977). Russkaya terminologiya-opyt lingvisticheskogo opisaniya [Russian Terminology - the experience of linguistic description]. Moscow: Nauka.

7. Doncu, R. E., Andronache, L. F. (2014). Greek and Latin Nomenclatures in Medical Language. Language and Literature - European Landmarks of Identity, 15, 348-352.

8. Dorland's Illustrated Medical Dictionary (2011). $32^{\text {nd }}$ edition. Philadelphia: Saunders.

9. Filippova, O. V. (2018). Krizovoe techenie arterial'noy gipertenzii na dogospital'nom etape: algoritm vedeniya patsienta [Crisis course of arterial hypertension at the prehospital phase: an algorithm for patient management] Russkij meditstsinskiy zhurnal [Russian Medical Journal]. https://www.rmj.ru/articles/kardiologiya/Krizovoe_techenie_arterialynoy_gipertenzii_na_dogospitalynom_etap e_algoritm_vedeniya_pacienta/.

10. Garifullina G. (2018). Ülep terelgän xatinniñ bala tabu tarixi: "Munchadaği par siman aq toman kürdem" [The birth history of a woman suffered clinical death]. Intertat. https://intertat.tatar/society/lep- terelg-n-khatynnybala-tabu-tarikhy- munchadagy-par-syman-ak-toman-k-rdem /

11. Garipova, F. (2015).Sinonimya v meditsinskoy terminologii bashkirskogo i turetskogo yazykov.[Synonyms in medical terminology of the Bashkir and Turkish languages].Filologiya $i$ chelovek.[Philology and man], 3,153163.

12. Gimadeev, M., Amirov, N., Ziyatdinov, K. (eds.), (2003).Meditsinskiy russko-tatarskiy tolkovy slovar' [Medical Russian-Tatar Defining Dictionary]. Kazan: Magarif.

13. Glendinning, E. H., Holmström, B. A. S. (2005).English in Medicine.Third edition. Cambridge: Cambridge University Press.

14. Glendinning, E. H., Howard, R. (2007).Professional English in use. Medicine.Cambridge: Cambridge University Press.

15. Grinev-Grinevich, S. (2008). Terminovedenie [Terminology studies]. Moscow: Academiya.

16. Khisamova, V. (2011). Vzaimosvyaz' ehtnokul'turnykh komponentov tatarskogo I angliyskogo yazykov v podgotovke professional'nykh perevodchikov v vuze.[The relationship of the ethnocultural components of the Tatar and English languages in the education of professional translators at the university]. Kazanskiy pedagogicheskiy zhurnal. [Kazan Pedagogical Journal], 1, 68-72.

17. Leychik, V. (2009). Terminovedenie. Predmet, metody, struktura [Terminology studies, Subject, methods, structure]. $4^{\text {th }}$ edtion. .Moscow: Librokom.

18. Leychik, V. (1973). Terminy-sinonimy, dublety, ehkvivalenty, varianty. [Terms-synonyms, doublets, equivalents, variants]. In Timofeev K (eds.). Aktual'nye problemy leksikologii i slovoobrazovaniya [Current issues of lexicology and word formation], vol.2, 103-107. Novosibirsk: Novosibirsk State University. 
19. Lotte, D. (1941). Nekotorye printsipial'nye voprosy otbora i postroeniya nauchno-tekhnicheskikh terminov [Some fundamental questions of the selection and construction of scientific and technical terms]. Moscow: Akademiya Nauk SSSR.

20. Medical slang terms nurses use (2018). Nursebuff. https://www.nursebuff.com/medical-slang/ (accessed 22 September 2018).

21. Motchenko, I. (2001). Osnovnye tendentsii v formirovanii angliyskoy meditsinskoy terminologyii [Main trends in the formation of English medical terminology]. Moscow: Moscow State Pedagogical University.

22. Natsional'nyy standart Rossijskoy Federatsii (2012). "Informatizatsiya zdorov'ya. Kontroliruemaya meditsinskaya terminologiya. Struktura i vysokourovnevye indicatory." [The national standard of the Russian Federation "Informatization of health.Controlled medical terminology. Structure and high-level indicators"].dated September 1, 2012. No. 54624-2011. Standardinform.

23. Novodranova, V. (2008).Imennoe slovoobrazovanie v latinskom yazyke i ego otrazhenie v terminologii [Noun word formation in Latin and its reflection in terminology]. Moscow: Yazyki slavyanskikh kul'tur.

24. Oxford Dictionary of Synonyms and Antonyms. $3^{\text {rd }}$ edition (2014). Oxford University Press

25. Polackova, G. (2001). Synonymy of medical terminology from the point of view of comparative linguistics. Bratislavské lekárske listy, 102 (3), 174-177.

26. Powell, K. (2018). They died of what? Historic causes of death.Thought.com. https://www.thoughtco.com/historic-causes-of-death-4034067.

27. Rajić, T. (2014). Euphemisms in Medical Jargon. Osijek: Jusip Juraj Strossmayer University.

28. Safiullina, F. (1999). Tatar teleneñ lexicologiyäse [Lexicology of Tatar Language]. Kazan: Xäter.

29. Salikhov, F. (2013). Ayaq tamiri kiñäyü-qurqyniç aviru. [Varicose veins of lower limbs is dangerous disease]. Irek mäidani [Liberty Square].http://www.im-kazan.ru/news/235.

30. Sell, R., Rothenberg, M. A., Chapmam, Ch. F. (2018). Dictionary of Medical Terms. $7^{\text {th }}$ edition. New York: Barrons Educational Series.

31. Senichkina, E. (2016). Slovar' ehvfemizmov russkogo yazyka [Dictionary of Russian euphemisms]. Moscow: Flinta.

32. Shamsutdinova, R. (2000). Meditsinskaya terminologiya v tatarskom yazyke [Medical terminology in the Tatar language]. Kazan: Kazan State University.

33. Shchekoldina, L. (2006). Kompleksnyy sopostavitel'nyy analiz anglijskoy i russkoy oftal'mologicheskoy leksiki [Comprehensive comparative analysis of English and Russian ophthalmic vocabulary]. Moscow: Moscow State Regional University.

34. Smirnova, E. (2011). Sinonimiya v sovremennoy meditsinskoy terminologii i ee leksikografirovanie (na primere anglo-russkikh slovarey). [Synonymy in modern medical terminology and its lexicography (based on the English-Russian dictionaries)]. Vestnik KGU im.N.A. Nekrasova [Bulletin of KSU named after N. Nekrasov], 2, 190-194.

35. Taranova, E., Bubyreva, Zh., Taranov, A. (2016). Problema sinonimii v spetsial'noy terminologii [The Problem of Synonymy in Special Terminology].Vestnik TGPU [TSPU Bulletin], 2 (167), 55-60.

36. Tolikina, E. (1970). Nekotorye lingvisticheskie problemiy zucheniya termina [Some linguistic problems of studying the term]. Lingvisticheskie problem nauchno-tekhnicheskoy terminologii [Linguistic problems of scientific and technical terminology]. Moscow: Nauka, 53-67.

37. Ulumbekova, G., Aleksandrovskiy, Yu. , Alyaev, Yu. (eds.) (2012). Bol'shoy entsiklopedicheskiy slovar' meditsinskikh terminov. [Large Encyclopaedical Dictionary of Medical Terms]. Moscow: GEOTAR-Media. 